Article

\title{
Review of White Roofing Materials and Emerging Economies with Focus on Energy Performance Cost-Benefit, Maintenance, and Consumer Indifference
}

\author{
Fadye Al Fayad ${ }^{1, *}$, Wahid Maref ${ }^{2}\left(\mathbb{D}\right.$ and Mohamed M. Awad ${ }^{3}(\mathbb{C}$ \\ 1 Business Administration Department, Jubail University College, Royal Commission for Jubail, \\ Al Jubail 35716, Saudi Arabia \\ 2 Construction Engineering Department, École de Technologie Supérieur (ÉTS), University of Québec, \\ 1100 Rue Notre-Dame Ouest, Montreal, QC H3C 1K3, Canada; Wahid.Maref@etsmtl.ca \\ 3 Mechanical Power Engineering Department, Faculty of Engineering, Mansoura University, \\ Mansoura 35516, Egypt; m_m_awad@mans.edu.eg \\ * Correspondence: Fayadf@ucj.edu.sa; Tel.: +966-500038138
}

check for updates

Citation: Fayad, F.A.; Maref, W.; Awad, M.M. Review of White Roofing Materials and Emerging Economies with Focus on Energy Performance Cost-Benefit, Maintenance, and Consumer Indifference. Sustainability 2021, 13, 9967. https://doi.org/10.3390/ su13179967

Academic Editor:

Alberto-Jesus Perea-Moreno

Received: 22 June 2021

Accepted: 30 August 2021

Published: 6 September 2021

Publisher's Note: MDPI stays neutral with regard to jurisdictional claims in published maps and institutional affiliations.

Copyright: (c) 2021 by the authors. Licensee MDPI, Basel, Switzerland. This article is an open access article distributed under the terms and conditions of the Creative Commons Attribution (CC BY) license (https:// creativecommons.org/licenses/by/ $4.0 /)$.

\begin{abstract}
This article performed a comprehensive review of the different state-of-the-art of roofing technologies and roofing materials and their impact on the urban heat island (UHI) and energy consumption of buildings. The building roofs are the main sources of undesirable heat for buildings, especially in warm climates. This paper discusses the use and application of white roofing material in emerging economies. The use of white roofing material is a suggestion because of its cooling, evaporative and efficiency characteristics compared to traditional black roofing materials. Many research studies have shown that the darker roofing surfaces that are prevalent in many urban areas actually can increase temperature by 1 to 3 degrees Celsius to the environment surrounding these urban areas. Additionally, improved temperature control and heat reflection also work to reduce the energy requirements for the interior spaces of the structures that have white roofing surfaces. The white or lighter colored roofs tend to reflect a part of the solar radiation that strikes the roof's surface. Consequently, one might believe that white roofing material would be commonplace and especially so within emerging economies. Yet, this is hardly the case at all. This paper examines the issue of white roofing materials in emerging economies from a dual perspective. The dual perspective includes the technical details of white roofing material and its impact on lowering the interior temperature of the affected structures, which consequently reduces hours of indoor thermal discomfort and use of air conditioners in indoor spaces. The other element in this study, however, involves the marketing aspect of white roofing material. This includes its adoption, acceptance and cost-benefit in emerging economies.
\end{abstract}

Keywords: white roofs; cool roofs; reflective material; cost-benefit; energy savings; urban heat island

\section{Introduction}

Global warming occurs when $\mathrm{CO}_{2}$ and other air pollutants absorb solar radiation that has bounced off the earth's surface resulting in an increase in the air temperature near the surface of the earth. As well, urban heat island effects contribute to global warming [1]. More recent research found that urban heat island effects contributed to climate warming by about $30 \%$ of all other issues that contribute to climate warming [2]. The study by [3] has shown increases in the severity of the effect of heat islands with the progress of climate change. Unlike vegetation and other natural ground cover, urban surfaces absorb and store more solar radiation, which leads to increasing the surrounding temperature $[4,5]$. It is important to point out that the higher surrounding temperature would cause a greater energy demand for air conditioning (A/C) systems [6]. Currently, there are five strategies that can be applied in order to mitigate the effects of urban heat islands [7-13]). These strategies include increasing vegetation and trees in urban areas [8], installing reflective 
pavements on streets, sidewalks and parking lots $[9,10]$, utilizing smart growth practices that help protect the natural environment [11], installing green roofs by growing vegetative layers on the rooftops [12], and installing cool/white/reflective roofing systems [6,13-17]. Throughout this paper, unless otherwise specified, cool roofs, white roofs and reflective roofs have the same meaning.

According to [18], surfaces in urban cities that are exposed to solar radiation are primarily rooftop surfaces. For residential buildings, the intense and prolonged solar radiation heats up the roof assembly more than any other building envelope component as the rooftop surface has the highest exposure to solar radiation [19]. Heat gain through residential roofs is primarily in the form of radiation [20]) and accounts for about $50 \%$ to $70 \%$ of the total heat gain into the indoor spaces below the ceiling board [21].

Because of the urban expansion phenomena, several materials especially artificial have been introduced into the market in order to replace the natural vegetation such as asphalt, limes, etc., which have affected drastically the environment and its temperature, thus energy consumption of buildings. To overcome to this phenomenon, many technology solutions have been investigated such as the use of vegetation [22,23], phase change materials (PCM) [22,24] and reflective coatings for claddings and roofing components [25] especially the use of the roof coating with high near-infrared reflectance (NIR) as to be an effective solution to mitigate the UHI. Therefore, $52 \%$ of absorbed heat is due to the near-infrared component of solar radiation. Ref. [26] has demonstrated in his paper that cool coating is one of the most effective solutions to mitigate the UHI on both facades and roofing systems. He uses cool coating that contains color pigments, which do not absorb the infrared portion of the solar spectrum.

Ref. [27] has studied the influence of traditional and solar reflective coatings on the heat transfer of building roofs in four cities with warm climates in Mexico. He has proven by simulation and experiments that uninsulated and insulated concrete slab white reflective roofs to have a daily heat gain between 37 and 56\% compared to uninsulated and insulated traditional slab roofs (gray roof).

Ref. [28] have focused in their research study on the modern residential roofs in Malaysia that employed mainly red and brown roof tiles due to aesthetic factors. The authors reveal the findings of their research study on the effect of roof tile colour on heat conduction transfer through roof tiles and ceiling boards, rooftop surface temperature and cooling load. They demonstrated that the selection of white roof tiles significantly reduces the peaks of heat conduction transfer and rooftop surface temperature as well as the values of heat conduction transfer and rooftop surface temperature throughout diurnal profiles, which consequently reduces hours of indoor thermal discomfort and use of air-conditioners in indoor spaces. A decline in peak rooftop surface temperature of up to $16.00{ }^{\circ} \mathrm{C}$ that results in annual energy savings of up to $13.14 \%$ can be achieved when the roof tile colour is changed from red to white.

Briefly, green roofs are mainly constructed by planting the rooftops of residential buildings [8,10-12]. In hot climates, shading the outer surface of the building envelope with green roofs has been shown to be more effective than increasing the amount of insulation. These roofs bring many benefits to the public, private, economic, social sectors, and the local and global environments. Both installation and the thermal performance of a green roof vary by the type and design, region, climate and building type. A list of benefits as a result of installing green roofs include:

- Green roofs reduce stormwater runoff where retention and/or delay of runoff eases stress on stormwater infrastructure and sewers.

- Green roofs enhance the energy performance of buildings due to reducing the heat flux through the roof. This results in fewer energy requirements for cooling during summertime and thus can lead to significant cost savings.

- Green roof's plant leaves trap dust particles from the air, and evapotranspiration cools ambient temperatures. This contributes to reducing global warming. 
- Green roofs cover the waterproofing membrane and thus protect it from UV rays and extreme daily temperature fluctuations. This protection extends the lifespan of the waterproofing membranes under green roofs in relation to traditional roofs.

- Green roofs can be designed to enhance urban food security through rooftop gardening and food production.

Generally, the external surfaces of different types of roof systems (traditional, green and cool) are exposed to several environmental factors that include dust/dirt, cloud coverage, sunlight, rain, snow, wind, outdoor temperature and relative humidity. The performance of the roofs depends mainly on these factors and the roof specifications $[6,14-17,29]$. The absorbed solar radiation on the external surfaces of the roofing systems causes an increase in the surface temperature of the roof, thereby increasing the cooling load in summer and reducing the heating load in winter [30]. Unlike traditional roofing systems, both green roofs and cool roofs are designed to reduce the amount of absorbed solar radiation. The cool roofs, which are the focus of this paper, use reflective materials or coatings that have high short-wave solar reflectivity (i.e., low short-wave absorption coefficient) to reflect a substantial portion of the incident solar radiation.

The influences of dirt and/or particles such as dust accumulations on surfaces are important for the solar photovoltaic (PV) panel and cool roof applications. For PV panels, the dirt/dust accumulations on the panels obstruct or distract light energy from reaching the solar cells, resulting in reduction in PV performance (e.g., see [31,32]) for more details). As provided in $[6,16,17]$ for cool roof applications, dust and dirt accumulations on the reflective materials or coatings installed on the external surfaces of roofs can decrease the short-wave solar reflectivity of these surfaces. This results in increasing the solar heat gains. Additionally, a number of studies reported on the change in the properties of roofing surfaces due to weathering factors and dirt accumulation, and also developed cleaning processes/procedures so as to minimize the loss in the solar reflecting of the rooftops [33-35].

The short-wave solar reflectivity is one of the most important properties for the reflective materials that have a great effect on the amount of energy savings $[14,15,36]$. Most recently, experimental and numerical studies were conducted to investigate the potential use of reflective roofing technology in hot, humid, dusty and polluted climates such as that in Kuwait and Saudi Arabia $[6,16,17]$. In these studies, the dust concentration on the surface of a Reflective Coating Material (RCM) that is currently available in the markets was measured in terms of the turbidity when the RCM was subjected to the natural weathering conductions of Jubail Industrial City (JIC). Additionally, due to the quite high pollution level in JIC [37,38], black carbon, inorganic carbon and some isolated dark spots of biomass can be seen on the surface of RCM as a thin layer between the coating and the dust. Beside dust, this thin layer of the contaminants can contribute to reducing the short-wave solar reflectivity of RCM. Furthermore, technical guide and cleaning processes were developed to increase solar reflectivity of the RCM that would result in high energy savings (see $[6,16,17]$ for more details).

For cool roofing systems subjected to hot climates such as that in Gulf Cooperation Council (GCC) countries, a simple and user-friendly design tool was recently developed [14,15]. This tool can easily be used by building engineers and architects for determining all pairs of the insulation thickness and the corresponding solar reflectivity of the reflective roofing materials/coatings that resulted in the same levels of the energy performance as those for the black roofing systems of thicker insulation thickness. As well, this design tool can be used to upgrade the building codes in order to allow using less insulation in the roofs if cool/white/reflective roofing systems are installed [17].

This section has introduced the concept of the different roofing systems that exist and made a difference between green/white/reflective/cool roofs, etc. and identified the advantages of these different roofing systems. 


\section{Technical Background and Cost-Benefit}

The use of white roofing materials is known to have thermal performance that makes it desirable in some climatic conditions and undesirable in others. The existing research indicates that solar energy striking roof structures have a significant effect on the thermal characteristics of the underlying structure. The use of white roofing material that is classified as a reflective surface material, relies on brightness as a means to reflect much of the short-wave radiation emitted by sunlight and striking the rooftop [36,39]. The result is, of course, a lower surface temperature of the roof material and therefore of the underlying structure. As such, the white roofing materials have affected significantly the interior heating and cooling energy loads of the structure itself.

On the technical side of this paper, some work on the specific materials that can be used in white roofs must be discussed. The feature of white roofs is much more involved than simply painting a roof with a reflective coating. Rather, reflective roofing material can be silicone-based and be painted or sprayed onto a structure or, alternatively, it can be a membrane material that is attached to the roof via adhesive [40]. Regardless of the specific material, the effectiveness of reflective roofing material is typically measured by determining the material's Solar Reflectance Index (SRI) rating. The SRI rating can see some materials that can reflect as much as $90 \%$ or more of the solar radiation striking the roof [41]. Regardless of the specific SRI rating, reflective roofing materials can take a number of different forms and applications and these should be discussed in some depth.

The costs of the reflective roofing materials along with the cost-benefit analysis can be a shared activity. The research process into costs of the materials itself is not technical but the ideal reflective roofing material for emerging markets does require some technical details such as its thermal properties, durability, etc. This is why costing and cost-benefit analysis benefits from a shared input format in this particular proposed article. The marketing element in the cost-benefit analysis can be integrated into the technical discussion either with a separate heading or as part of the overall discussion.

\subsection{Application and Maintenance}

The application process of white roofing material requires technical knowledge as does the maintenance processes involved. Yet, the maintenance processes involved in white roofing materials must also be known from a marketing perspective. This is because emerging economies typically have limited resources available. At a granular level, however, entities that utilize white roofing materials as a means to reduce the cooling energy load of a structure, reduce environmental heat build-up and as well seek to control costs have to consider the post-application phase of the material. As mentioned, the technical application of the white roof depends upon the form of white roofing material selected. Likewise, the maintenance is also dependent upon what material is selected. In effect, cost factors must also be considered with respect to ongoing maintenance of white roofs in developing markets.

\subsection{Link between Reflective Roofing Material and Emerging Economies}

This section introduces the concept of emerging economies and identifies the relation that exists between the reflective roofing materials and emerging economies.

Emerging markets are the centrepiece of global economic growth. As such, it is important to identify the link between reflective roofing material and emerging economies. In order to fully explore this link, one must first characterize what is meant by an emerging market. Emerging markets are those markets that are in the process of transitioning from a developing market to a developed market. They are characterized by some degree of market volatility, high growth potential for investors, and tend to have low to middle per capita income rates across their general populations. The link between energy demand, energy consumption, and climate change through the production of greenhouse gas emissions is irrefutable. While developed countries typically have the resources necessary to both develop new construction designs and technologies to reduce energy consumption 
and emissions, emergent economies lack such resources. Consequently, without an understanding of how to improve building design, efficiency, and construction in emergent economies, reducing global greenhouse gas emissions and especially carbon dioxide $\left(\mathrm{CO}_{2}\right)$ will be largely impossible. Research has demonstrated that as much as $75 \%$ of all energy demand involves industrial activities and/or buildings located in emerging economies globally [42]). Thus, even if developed markets are fully successful in reducing overall energy consumption, emissions, and gaining sustainability, climate change will continue unabated due to inefficient activities in emerging economies.

The use of passive energy efficiency designs is critical in any economy as a means to reduce energy consumption, achieve sustainable energy usage patterns and to reduce the human impact on global warming. Passive energy design-build techniques by definition do not require ongoing energy commitments in the same way that active or non-passive design-build solutions do. However, in emerging economies, such passive building designs are extremely important. This is because emerging economies tend to lack the resources necessary to reverse integrate more energy-efficient solutions with respect to energyefficient materials used in building construction. This importance with respect to emerging economies can be seen in the degree to which energy consumption increases. For example, on average, overall energy consumption globally among all countries is expected to increase by more than $100 \%$ by the year 2050 but in emerging economies, this figure is believed to be more than $300 \%$ on average [43]. Hence, if emergent economies can deploy energy-efficient building designs and integrate energy-efficient building envelope materials at the outset, they can reduce this dramatic gap in expected energy usage growth moving forward. Specifically, in the design phase of new construction, passive energy-efficient solutions greatly reduce forward energy demands per structure.

In fact, the design-build phase of construction in emergent economies can address issues that have significant positive effects on energy consumption throughout the life of the structure. Even more pertinent to emergent economies is the fact that such solutions during the design-build process often do not come with excessive upfront costs if addressed during this phase. This is as opposed to addressing them later on during a deep restoration later in the structure's lifespan. Such solutions during this design-build phase include the simple use of increased insulating material, improved fenestration that reduces solar loading, the use of reflective surfaces including roofing material on all structure envelopes, improved sealing techniques, and designing out what are referred to as thermal bridges beneath the roof structure that conduct heat into the interior of the building [44]. All of these solutions reduce the energy use of the structure throughout its lifespan and work in conjunction with reflective roofing surfaces. The use of supplemental design-build solutions that address long-term energy use and demand work to amplify the positive effect of reflective roof materials in the operating costs of the structure over its entire lifespan. The result is structured so that it not only reduces the use of energy required to operate them on a long-term basis but also reduces the cost or even the necessity for major restorations in order to achieve long-term sustainability in the future. Such major restorations are themselves very costly and resources dependent which presents additional problems for emergent economies.

One aspect of energy-efficient building construction and materials such as the use of reflective roofing material that is often overlooked involves the financial element. This particular element is especially important if it is considering an emerging economy. The observation is that most if not all emerging economies implemented more energy-efficient design-build solutions if they were able to manage such solutions financially. Sustainability in energy use, usage growth, and zero-carbon emissions may be able to be achieved without significant cost increases but such solutions often require sophisticated financial structures during the funding process of a structure. Thus, emerging economies can benefit greatly from implementing sustainable finance methods as a precursor to new building design and construction. These are financial structures that include instruments such as blended financing, social responsibility factors, and green finance structures that are introduced as 
a criterion to foreign direct investment or FDI [42]. These types of financial structures are focused on building design and construction techniques that are inherently more energyefficient than would otherwise be the case. This reduces the inclination within emerging economies to award construction contracts based purely on upfront costs. In essence, design-build solutions that are based primarily on upfront costs typically result in dramatically higher operating costs over the lifecycle of a structure. In essence, such long-term lifecycle costs ultimately end up costing more than the estimates for more energy-efficient design-build solutions. That is, energy-efficient financial structures incentivize energyefficient design-build solutions for both local and outside economic participants.

Much of the need for both financial and technological energy-efficient solutions in emergent economies relates to the specific idiosyncrasies of emerging economies themselves. In effect, while developed markets do tend to have a high percentage of established infrastructure in place, emerging economies are still in the process of building out much of their internal infrastructure. Thus, where developed markets are both implementing new energy-efficient building construction techniques and directing enormous amounts of capital towards deep restorations of existing structures, emergent economies are focused primarily on building new infrastructure. This dynamic is expressed in certain ways with an emphasis on the type of energy that is utilized to fuel economic activity itself. For instance, countries such as Vietnam still rely heavily on dirty energy sources such as coal to support economic activity and Ethiopia which still needs to electrify some $50 \%$ of its market [45]. The net result is such that almost all of the downstream activity in these and similar emergent economies such as new building construction, employ solutions that themselves are inherently inefficient.

Still, in regards to emergent economies, the overall emphasis on sustainability in building design and construction must remain on the integration of efficient building techniques. Therefore, the use of reflective material in emerging markets is primarily the same as it is in developed markets. Yet, the scope and scale of reflective building design and construction techniques should be broadened for emerging markets simply because of the lack of resources compared to developed markets. The resource has demonstrated that the use of reflective roofing material as well as reflective material on other envelope structures is quite simply the most effective way to reduce the energy requirements necessary to cool/heat a structure. Yet, one other consideration that emerging markets can easily integrate into their development plans during the design-build process for new structures is to consider the reduction of urban heat islands in which heavily urbanized developments themselves become heat sinks [46]. Such heat sinks contribute to the energy requirements for the structures that exist within them. Hence, designing the development pattern of economic centres can contribute to the reduction of heat loading of a given structure. Additionally, emerging economies can further improve the effectiveness of reflective roofing solutions but augmenting them with solutions such as radiant barriers that block the transmission of any solar energy that does infiltrate the structure [47]. Regardless, emerging economies have a range of alternatives within the design-build phase of new construction that they can avail themselves of. Combined, the overall effect is the reduction not only of energy requirements but of future energy requirement growth.

Emerging economies experience certain economic and construction issues that developed markets do not. These issues are primarily resource-related as well as technologyrelated with respect to cost, affordability, and even availability. Yet, as this section has indicated, emergent markets tend to also experience sustainability issues involving energy efficiency due to a lack of financial sophistication in the funding process for new structures. These particular issues can prevent a new structure from being able to maximize energy efficiency at the outset resulting in the need for a deep restoration earlier in a structure's lifecycle than might otherwise be the case. Other solutions for emerging economies involve design-build techniques such as site selection and radiant barriers that reduce the long-term growth in energy demand itself. 


\section{White Roofing Systems Cost-Benefits}

Many previous studies [4,48-57] including this current study have shown that green and reflective roofs are not only protection from solar radiation and rain but can save energy, mitigate urban heat islands, decrease greenhouse gas emissions, and reduce local air pollution while increasing the thermal comfort level (i.e., indoor air quality). The reflective roofs are widely known in the markets as white roofs and cool roofs. Ref. [58] have used the DOE-2 energy simulation tool to investigate if the reflective roofs have an effect on the heating and cooling energy use for buildings in the USA. That study showed that the estimated net saving of about $\$ 750 \mathrm{M}$ in annual energy payments for an annual electricity savings around 10 TWh and the peak electrical power reduction was about $7 \mathrm{GW}$.

Ref. [59] have shown in their study on a single-family one-storey building that by increasing the reflectivity of the roof from $20 \%$ to $60 \%$ is equivalent to a $50 \%$ reduction of the roof insulation thickness in hot climates. This comes to support the introduction of the reflective roof materials in the proposed ASHRAE SSPC 90.2. Four prototypes of commercial buildings in 236 US cities have been simulated by [60] in order to determine their annual cooling and heating energy loads. In that study, a short-wave solar reflectivity of $55 \%$ has replaced the cool roof and with short-wave solar reflectivity of $20 \%$ by a conventional grey roof. The results showed that the cool roofs showed an annual energy saving per unit conditioned roof area fluctuating from $\$ 1.14 / \mathrm{m}^{2}$ in Arizona to $\$ 0.126 / \mathrm{m}^{2}$ in West Virginia ( $\$ 0.356 / \mathrm{m}^{2}$ the rest of the USA).

The study by [61] has shown that energy saving is highly dependent on roof type, climate and quantity of insulation used for cool and green roofs. As an example, for a typical one-storey building in Boston with a modified-bitumen roof and a thermal resistance RSI of $2.7 \mathrm{~m}^{2} \mathrm{~K} / \mathrm{W}$ ( $R$-value of $15.3 \mathrm{ft}^{2} \mathrm{~F} \mathrm{hr} / \mathrm{BTU}$ ), if you double the insulation thickness, you can save $13 \%$ in cooling and heating energy. However, when you install a green roof instead, you can save $12 \%$ energy. However, for the same building in Lisbon (Portugal), and by adding twice the quantity of the insulation, the results showed that there is almost no energy saving, whereas by installing a green roof, the result shows $26 \%$ reduction in energy use [61].

\section{Energy Performance and Energy Saving in Buildings and Its Effect on the Environment in Hot and Cold Climate Zones}

The continuous increase for example of greenhouse gas (GHG) emissions, the precipitation intensity and the atmospheric temperatures were the direct consequences of global warming. A high percentage of the local and global effects of climate change have been impacted by buildings and other infrastructures. In hot climate zones such as Saudi Arabia, most of the energy is used for cooling, which impacts directly global warming.

Ref. [57] have shown that $30-40 \%$ of the total energy demand is due to the high energy consumption in buildings. This can be different from one geographical zone to another, such as in Europe, the buildings are responsible for about $40-50 \%$ of energy use. A large portion of this energy is used for heating (European Commission 2010). Figure 1a,b and ref. $[62,63]$ show that in Canada, the third important sector of energy use and GHG emissions is the building sector, just after industry and transportation, which is about $27 \%$ and $23 \%$ respectively. 


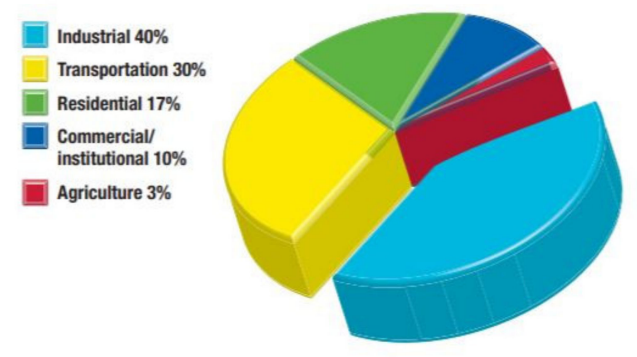

(a)

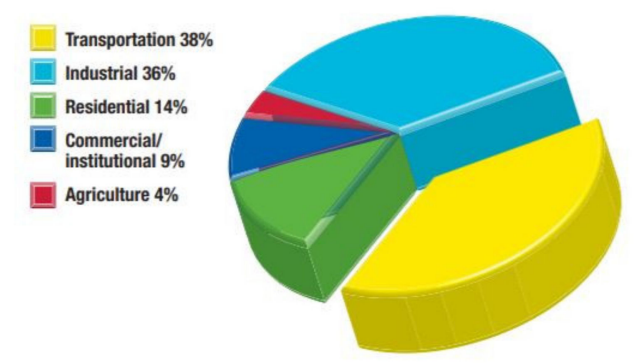

(b)

Figure 1. (a) Secondary energy use by sector $[62,63]$. (b) GHG Emission by sector $[62,63]$.

The secondary energy use (Figures $1 \mathrm{a}, \mathrm{b}$ and $2 \mathrm{a}, \mathrm{b}$ ) is the energy used by final consumers in various sectors of the economy, GHG emissions by sector and distribution of residential and commercial energy use respectively. This includes, for example, the energy used by vehicles in the transportation sector. Secondary energy use also encompasses energy required to heat and cool homes or businesses in the residential and commercial/institutional sectors. In addition, it comprises energy required to run machinery in the industrial and agricultural sectors. Energy is used in all five sectors of the economy: residential, commercial/institutional, industrial, transportation, and agriculture. The industrial sector accounted for the largest share of energy, followed by transportation, residential, commercial/institutional, and agriculture.

Space heating $63 \%$ Water heating $19 \%$ Appliances $12 \%$ Lighting $4 \%$ Space cooling $1 \%$

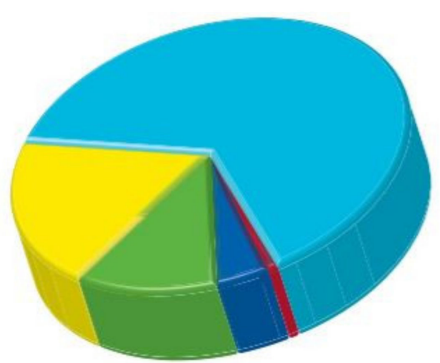

(a)

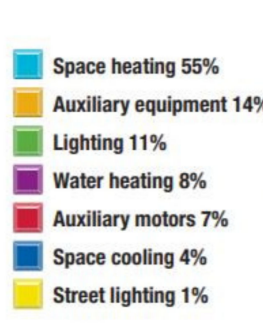

(b)

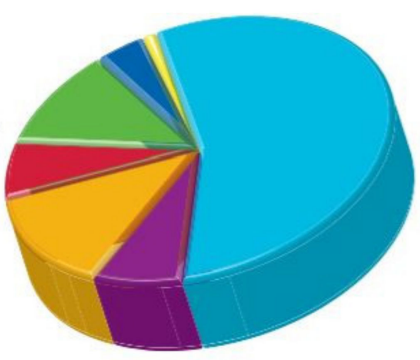

Figure 2. (a) Distribution of residential energy use by end use [62,63]. (b) Commercial/Institutional energy use by end use [62,63].

On the contrary, in hot climate zones such as in GCC countries, a large portion of the energy is used for cooling. Ref. [51] have shown in their study that in Kuwait, 90\% of the electricity consumption is due to buildings, where $70 \%$ of the electricity peak demand in 2004 is due to the residential sector. The authors reported as well that in Canada (Figure $1 \mathrm{a}, \mathrm{b}$ ), the residential sector used about $17 \%$ of the energy where about $10 \%$ for the commercial and institutional sector are responsible for $14 \%$ and $9 \%$, respectively, for the GHG emissions. Figure 2a,b shows the distribution of secondary energy use in residential and commercial/Institutional energy use by end-use. Figure 2a shows that the largest share in the distribution of energy use by end-use in residential buildings is the space heating which represents about 55-63\% in commercial buildings (see Figure $2 b$ ).

In order to save energy in buildings, the building envelope design (i.e., walls, roofs and fenestration systems) plays a pivotal role. The energy conservation efforts will mainly not only reduce the energy consumption but also the GHG emissions by $50 \%$ (Figure 3) (see [64] for more details). As such, having a holistic approach is the best for energy efficiency. The first step is to improve the building envelope performance even before improving the energy performance of the mechanical systems. 


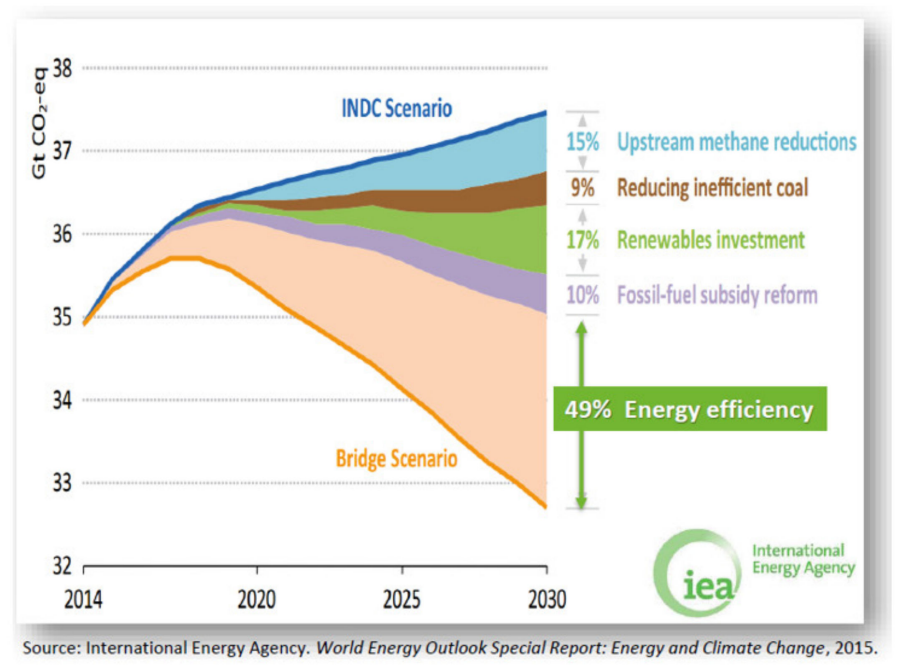

Figure 3. Energy Consumption and GHG Emissions [64].

This research study focuses only on one part of building envelope, which is the cool roof system. Using an urban canyon model coupled to a global climate model, [4] have studied the impacts of globally installing cool roofs. The results showed that a reduction by $33 \%$ in the annual heat island can lead to reducing the daily maximum and minimum temperatures by $0.6{ }^{\circ} \mathrm{C}$ and $0.3^{\circ} \mathrm{C}$, respectively. In order to attenuate the effect of global warming a reduction of the energy demand for building operation will help and which imply a reduction of operating cost. This can be achieved by designing a high-performance building envelope having roofing systems with high potential of energy savings at no risk of condensation and its related problems such as mold growth [52,65-67].

Roofing systems have evolved in the construction industry. A "green" roofing has evolved for many decades now, and it contributes more and more in helping the environment by reducing GHG emissions and fighting against global warming in general. In order to enhance the roof's contribution to environmental requirements, "green" roofing has evolved into one of two types: highly reflective or "cool" roofing systems, and vegetative roofing systems. Ref. [67] presented a practical decision-making procedure for designing and selecting a sustainable green roofing system. In that study, the author considered several roofing assemblies available in the market, compared the disadvantages and advantages of each, and illustrated which assemblies meet cool roofing and vegetative roofing guidelines. That study also offered a good understanding of "green" roof options that are viable for different types of buildings [67].

Short-wave solar radiation consists of ultraviolet, visible light, and near-infrared radiation from the sun that reaches the Earth. The latter is one of the key drivers of urban heat islands. Urban surfaces reflect less solar radiation back to the environment. Instead, more solar radiation is stored and absorbs resulting in an increase in the temperatures of the surrounding $[4,5,13,68]$. Using cool pavements for example (either reflective or permeable) on parking areas, sidewalks and streets to reflect more solar energy back to the atmosphere. The temperatures of the surfaces of the pavement and the surrounding air are lower than traditional pavements because of the use of cool pavements [11]. To improve the urban climate during the heat waves, [21] used smart wetting of building materials and [69] evaluated the effect of different cool pavement strategies on the heat island mitigation. For example, in a city of 1 million inhabitants or higher, the annual mean air temperature can be higher than its close environment by $1{ }^{\circ} \mathrm{C}$ and $3{ }^{\circ} \mathrm{C}$. In the nighttime, however, the difference can reach $12{ }^{\circ} \mathrm{C}$ or higher because the built environment radiates the heat absorbed during the daytime [5].

When the surrounding temperature increases, it means not only air conditioning systems demand will increase but also their coefficient of performance will decrease, which 
results in more energy consumption to operate these systems. Additionally, urban heat islands are not only uncomfortably warm, but are also smoggier. This is due to smog composition from the photochemical reactions of air contaminants can result in increasing air temperatures. For example, [68] showed that in some cities, the incidence of smog increases $3 \%$ for each degree higher than $21^{\circ} \mathrm{C}$.

According to the U.S. EPA [5], five approaches that can attenuate the impact of the urban heat island were recommended. These approaches include:

(1) Growing more trees and green areas in places with a potential of the urban heat island. This helps lower surface and air temperatures by providing shade and cooling through evapotranspiration. Note that plants absorb water through their roots and emit it through their leaves. This movement of water is called transpiration. As well, evaporation also occurs from vegetation's surfaces and the surrounding medium. The transpiration and evaporation together are called evapotranspiration. Consequently, evapotranspiration cools the air by absorbing the heat from the surrounding air to evaporate water [13].

(2) Installing green roofs by increasing a vegetative layer on the rooftops. The vegetative layer provides shade. This aids a decrease in the temperatures of the roof surface and the surrounding air. Another benefit of installing green roofs is that they have high thermal mass that attenuates the variations of the temperature on buildings during the day, which can help improve building comfort and as well reduce peak energy demands. Note that thermal mass is the ability of a material to store heat. During peak temperature hours, a material with high thermal mass absorbs heat rather than transfer it to the living space. This keeps the interior of the home comfortable during peak temperature hours. At nighttime, the absorbed heat is released, helping the home to stay warm. Correct use of thermal mass can delay heat flow through the building envelope by as much as 10 to $12 \mathrm{~h}$. This produces a warmer house at nighttime and during winter months and a cooler house during the daytime and summer months. As of July 2012, there were nearly 59,000 completed green home projects in the United States, most of which were single-family homes with detached garages [70].

(3) Installing cool/reflective/white roofs, which is the focus of this paper. These roofs use roofing materials (e.g., Membranes and coatings) with high short-wave solar reflectivity. Good roofing systems can insulate, reduce heat transference and help save electrical energy. This eventually reduces the carbon footprint due to the reduction of the dependency on fossil fuels. In the United States, different types of reflective roofs have been used for more than 20 years [13]. Several studies on reflective roofs have shown a reduction in roof surface temperatures and energy demand that is needed for buildings [14,15,36,39,55,71-73].

(4) Applying innovative practices. These cover a variety of development and preservation approaches to protect the environment [5]. Because of the importance of reflective and green technology for saving energy in buildings, a workshop [74] entitled "Green Technologies and Energy Efficiency (GTEE 2017)", was held on 26 April 2017, at the King Faisal University in Saudi Arabia. Among many goals of this workshop, two of these goals were to: (a) gather experts in green technologies and energy efficiency and initiate communication and cooperation channels within the framework of the Kingdom of Saudi Arabia (KSA) 2030 Vision, and (b) initiate green technologies and energy efficiency-related research activities by institutions and companies.

This section explored how the energy demand has increased drastically in the last 10 to 20 years and what are the main factors that affect energy consumption negatively. It clarified how roofing technologies can be part of the solution in energy savings in hot climate zones, for example.

\section{Marketing Considerations and Cost Benefit}

The marketing discussion in this article addresses factors involving cost-benefit, maintenance and how the technology is adopted. In terms of the cost-benefit, it has to be 
understood that emerging economies often have limited capital and material resources. These factors have to be accounted for when introducing a new technology such as white roofing materials. If the cost to adopt the technology outweighs the long-term operational savings of the white roof material, then there is little rationale for the technology to be supported by either government or private enterprise. Among some of the cost factors involved in the cost-benefit are those such as the upfront cost of the material, the maintenance cost associated with specific technology deployed, the long-term cost savings associated with a particular white roof application and the durability of the specific material selected [40]. If not all of these factors are considered, then the targeted emerging economy is less likely to consider any such technology adoption.

Still, as is often the case in emerging markets, the general population has certain reservations about any technology uptake that is accompanied by increased costs. Furthermore, the type of roof structures that predominates in a given market also affects the decision to deploy the technology as well. If the constituents in the emerging economy believe that the white roofing material selected is less durable and thus more costly in terms of replacement frequency, no amount of marketing convinces them to adopt it. The fact is that how this technology is marketed to the constituents in the emerging economy is ultimately the factor that leads to its adoption or denial. One aspect of the marketing message with respect to white roofing materials that must be emphasized is durability since temperature is a main factor in durability where black roofs typically experience higher temperature. Additionally, the associated benefits of cooler interior temperatures, lower cooling costs and, in general, improved visual appearance of white roof materials should form the nucleus of the marketing message. Increasingly, the most relevant themes then in white roofing technology relate to global climate change.

The two unique features of white roofing materials that make its marketing and advertising much more feasible in the open market involve their inherent energy efficiencies and enhancing the indoor air quality (i.e., increasing the comfort level). White roofing materials and cool roofs in general have two unique features that differentiate them from other roofing materials vis-à-vis energy-related factors. The two unique features that have been discussed from a technical perspective in other sections of this study include: (1) white roofing materials have a higher solar reflectance factor than do traditional roofing materials, and (2) white roofing materials or cool roofs have a greater capacity to release heat that has been absorbed into the material and is usually given as a ratio somewhere in between 0 to 1 [75]. From a technical perspective, these two points are extremely important as they essentially determine the overall energy efficiency of the roofing system. However, from a marketing perspective, these two points offer enormous leverage in the marketing collateral developed to sell and market these materials to the public, contractors, and civil governments and agencies.

It should be noted, of course, that not all cool roofs are comprised of white roofing materials. However, white roofing materials are typically the easiest method to capture these benefits of cool roofing technologies because they are inherently more solar reflective than other colors and usually has a higher level of thermal emittance (i.e., higher longwave thermal emissivity), which helps radiate more of the absorbed heat by the rooftop back to the environment. Any type of product or service that is sold and marketed to the public, corporate entities and government agencies benefit from marketing messaging that accurately communicates what exact properties about the product or service that differentiate them from others in their respective markets or industries [76]. Given this, cool roof technologies and white roofing materials would both benefit from marketing messaging that accurately captures what exactly differentiates them from traditional roofing technologies. Thus, a marketing message that succinctly informs the targeted consumer that white roofing materials and cool roofs save an enormous amount of energy and operate much more efficiently due to their thermal emittance are two themes that immediately capture the consumers' attention due to global factors such as climate change, peak oil and environmental decay [77]. Hence, consumers, whether public or private, government 
or corporate, all have some level of interest in cost savings. In addition, when such costsavings can simultaneously benefit the earth's environment, the consumer benefits through goodwill, public relations and corporate social responsibility-related factors.

Yet, developing an effective marketing plan along with associated marketing messages might be difficult when speaking of esoteric technologies such as roofing materials. The marketing message that is developed for the target markets has to make the rationale for adopting such roofing solutions palatable from a cost-benefit perspective but also from a public relations/social equity perspective. In this regard, the marketing collateral developed to sell and market white roofing materials and cool roof technologies should address some or all of the following elements in one fashion or another [77]:

1. Characterize the lifecycle expectations associated with the roofing technology selected

2. Determine for the consumer how well the roofing technology will survive over time

3. Inform the consumer how the material resists the phenomena such as mold, mildew and discoloration

4. The cost of repairing any damage to the roofing technology

5. The routine cost of maintenance and upkeep of the roofing technology

6. Identifying what the installation process requires in terms of time and cost

7. Who is installing the roofing technology and are the installers skilled in the selected materials

8. The flexibility of the roofing technology selected during extreme fluctuations of temperature.

It is important to spend the necessary effort to fully explore each of the eight factors above prior to the development of a marketing platform for white roofing materials and cool roof technologies in order to ensure that the resulting marketing plan comprehensively responds to consumer needs. As well, some of these marketing-related initiatives must be tailored to those markets where white roofing and cool roofing technologies are more inclined to be installed.

\section{Cool Roofs Pros and Cons and Its Relationship with the Weather}

In the design stage of roofing systems, the energy savings and risk of condensation are important. The moisture-related problems can lead to deterioration of roofing materials and affect negatively the thermal performance by means of reduction in overall thermal resistance and service life of the roofing systems. This can lead as well to mold growth in those systems and affect the indoor air quality (IAQ) and the occupants' health and comfort [14,15,76-82].

The roof surface reflectivity can affect the quantity of the absorbed short-wave energy of the roof. Since the short-wave solar radiation has the capacity during the summer and daytime to dry out the roof, the solar reflectivity becomes an important parameter for the selection of roofing materials $[6,14,15,36,39,83]$. The characteristic of the cool roofs is to maintain surface temperatures lower than those from the black roof (dark) because of its low short-wave solar absorption coefficient. This may lead to moisture-related problems in cold climate zones [84] as such observed for both black and cool roofs [14,15]. Several studies have investigated the moisture-related problems due to the colour of the roofing membrane in commercial buildings with a low slope such as in [85] research. Their study was done for cold climate with the focus on single-ply roofing systems with highly reflective materials, white TPO/PVC and black membranes, where they are attached mechanically on low slope roofs $(\leq 2: 12)$. In this research study, hygrothermal simulations were conducted for a one-year period on those roofing systems for the following cities in the USA: Boston, Albany, Chicago, Cleveland and Detroit. Two cases were studied: (i) $10 \%$ short-wave solar reflectivity for black roofs, and (ii) $70 \%$ short-wave solar reflectivity for white roofs. Since those systems are mechanically attached to the metal deck and to account for the leakage due to the attachment, the vapour permeance of metal was taken at 0.75 perms. The results showed that even there is condensation below the membrane TPO/PVC in the winter, all roofs have dried out in the summer. 
Hygrothermal simulations were conducted [86] for a 5-year period. They explored the moisture accumulation in different roofing systems (i.e., white with $80 \%$ short-wave solar reflectivity and black roofs with $12 \%$ ) for different cities in the USA and Germany (Phoenix, AZ, Chicago, IL, Anchorage, AK, and Holzkirchen, Germany). The results of this study showed that the white roofs have more moisture accumulation than the black ones. Three roofing systems cases, dark, bright and shaded flat roofs, have been studied by [87] for their hygrothermal performance with initial construction moisture. In the summer, the results showed that the bright roofs have the lowest surface temperatures with a smaller drying potential than the two other roofing systems. The highest surface temperature and humidity fluctuations were shown in the dark roofs with high heat fluxes. The roof with shaded surfaces has shown as well a low temperature and drying potential.

Hygrothermal simulations on white and black Modified-Bitumen (MOD-BIT) roofing systems have been conducted by $[14,15])$ to evaluate their energy and moisture accumulation for different climate zones in North America based on their Heating-Degree-Days (HDD) such as Toronto (ON), Montreal (QC), St. John's (NL), Saskatoon (SK), Seattle (WA), Wilmington (AZ), and Phoenix (AZ). In the cities of St. John's and Saskatoon, the white roofs showed the highest moisture accumulation over time than the black ones which could lead to moisture damage. On the contrary, there is no risk for the black roofs. The simulation results for Toronto, Montreal, Seattle, Wilmington, and Phoenix, showed that the white roofs have a low risk of experiencing moisture damage. The yearly heating loads of the white roof were slightly higher than that of the black roof. Conversely, the yearly cooling loads of the black roof were much important than the white roof. Thus, buildings with white roofs in these locations are predicted to result in net yearly energy savings compared to buildings with black roofs.

Most recently, several researchers [14-16,72-88] conducted several studies to investigate the performance of cool and black roofs in terms of energy and moisture when they were subjected to different hot and humid climates in GCC countries. These studies covered several thicknesses of roof insulation material and surface solar reflectivity. These roofing systems showed no risk of condensation, thus, no risk of mold growth and roofs with high solar reflectivity showed significant energy savings. For the Eastern Province of Saudi Arabia and Kuwait City, respectively, the highest hourly surface temperatures of the black roofs were found to be $93.2^{\circ} \mathrm{C}$ and $84.0^{\circ} \mathrm{C}$ compared to $65.4^{\circ} \mathrm{C}$ and $61.5^{\circ} \mathrm{C}$ for a white roof at no cleaning condition, and $52.7^{\circ} \mathrm{C}$ and $52.6^{\circ} \mathrm{C}$ for white roofs at weekly cleaning conditions. The full results of that study that include material characterizations, installing guidelines, cleaning procedures, test results, three-dimensional numerical results, etc., are available in $[69,70]$.

\section{Application and Maintenance of Cool Roofs}

The application process of white roofing material requires technical knowledge as does the maintenance processes involved. Yet, the maintenance processes involved in white roofing materials must also be known from a marketing perspective. This is because emerging economies typically have limited resources available. At a granular level, however, entities that utilize white roofing materials as a means to reduce the cooling energy load of a structure, reduce environmental heat build-up and as well seek to control costs have to consider the post-application phase of the material. As mentioned, the technical application of the white roof depends upon the form of white roofing material selected. Likewise, maintenance is also dependent upon what material is selected. In effect, cost factors must also be considered with respect to ongoing maintenance of white roofs in developing markets.

The exterior surface of the roofing system is exposed to dust/dirt, rain, snow, wind, cloud index, exterior temperature and relative humidity, etc. All these external conditions as well as the roofing systems specifications (components, dimensions, etc.) could affect the roofing system's thermal and hygrothermal performance. As shown in Figure 4, when solar radiation hits the surface of a roofing system, a portion of this energy is reflected and the other portion is absorbed. Due to this energy absorption, the roof's 
surface temperature increased, thus in the summer, the cooling energy load increased and in the winter, the heating energy load decreased. On the other hand, white roofing systems use surfaces with low short-wave solar absorption coefficient to show a significant portion of the incident short-wave solar radiation, and therefore, lowers the cooling energy load and as well the roof's surface temperature compared to black roofing systems.

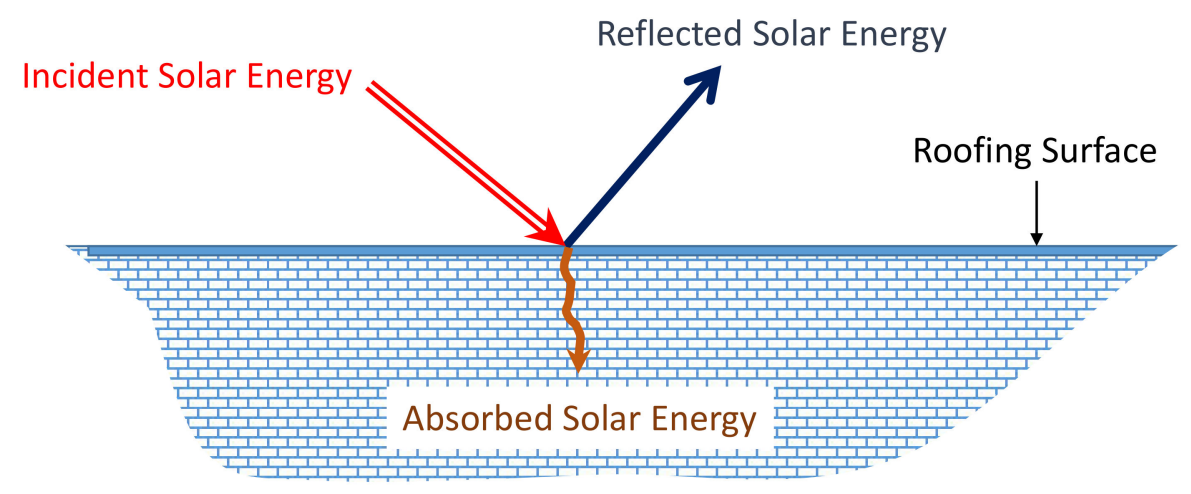

Figure 4. Schematic of roofing surface subjected to incident solar energy.

The surface solar reflectivity can be affected negatively by the accumulation of dust or dirt on those surfaces, which can result in increasing solar heat gains. Several researchers [29,30,33-35] have investigated the negative effect of the dust or dirt accumulation and weathering factors on the roofs' thermal properties. Additionally, several cleaning processes of dust or dirt on roofing systems' surfaces have been established to bring back roofing surfaces' solar reflectivity to its original value such as in Levinson et al. [34] studies on light-coloured roofing membranes' solar heat gain.

In the study [34], several roofing membranes with white or light gray polyvinyl chloride collected from different locations in the USA were tested. Black and inorganic carbon were found on the surface of the sample. These contaminants reduce the solar reflectivity of these membranes. To analyze the influence of several cleaning processes on the solar reflectivity values, the sample surfaces were firstly wiped to mimic the action of the wind action, then rinsed to mimic rain effect, and they were washed in the third step to simulate a homemade cleaning process using a phosphate-free dishwashing detergent. As a final step, all the surfaces were treated with sodium hydroxide and a mixture of sodium hypochlorite to mimic real cleaning processes. The outcomes of study [34] showed that after washing and rinsing processes, almost all the dirt deposited on the surface was removed except for thin layers of organic carbon and some isolated dark spots of biomass. Bleaching processes cleared these last two contaminants recovering the loss of solar reflectivity.

Akbari et al. [35] used an identical cleaning process established in [34] on unweathered (i.e., new materials) and weathered single ply roofing membranes from several North American sites. In this research study, 16 types of roofing materials were tested at Lawrence Berkeley National Laboratory (LBNL), following all the cleaning processes concerning the weathered samples surface treatment, and 25 other types were tested at the National Research Council of Canada, applying just wiping processes on the surface of the roofing material. The results showed that all types of cleaning recovered near $90 \%$ of their unweathered solar reflectivity and thus, showed their effectiveness.

To the best of our knowledge, most (if not all) previous studies related to characterizing the impact of dust or dirt accumulation on the rooftops and its impact on cool roofs' energy performance were conducted in non-dusty climates. As such, a new joint research study between the KSA's Jubail University College (JUC) and Kuwait Institute for Scientific Research (KISR), called "JUC-KISR project" was initiated to address this issue in a dusty climate. Several roofing materials with different emissivity are currently being tested and numerically modelled under the dusty and polluted climate of KSA's Jubail Industrial 
City. The objectives of JUC-KISR project include: (i) motioning the short-wave solar reflectivity's variation of the tested materials, (ii) developing a technical guide for dust and dirt cleaning processes for the tested materials, and (iii) quantification the effect of dirt and dust accumulation of on the overall roofing systems' energy and moisture performance. The developed technical guide will be proposed later to International Organizations such as ASTM or ASHRAE to develop an international standard for the cleaning procedure of different reflective materials for use in residential and commercial buildings when they are subjected to dusty and non-dusty climates.

In the JUC-KISR project, one of the reflective coating materials was characterized and tested under the highly polluted and dusty weather of Jubail Industrial City. Thereafter, this reflective coating material was used in one of the most common roofing systems in GCC countries when it was exposed to Kuwait City and Eastern Province of Saudi Arabia's environmental conditions. For Saudi Eastern Province climates, Figure 5 shows that the yearly cooling load (EC, Y) of the conventional/black roof $(1077 \mathrm{Wd} / \mathrm{m} 2)$ decreased to $706 \mathrm{Wd} / \mathrm{m}^{2}$ (i.e., a reduction in EC, Y by 53\%) and $563 \mathrm{Wd} / \mathrm{m}^{2}$ (i.e., a reduction in EC, $\mathrm{Y}$ by $91 \%$ ) as a result of installing reflective coating material at no cleaning condition and weekly cleaning condition, respectively. Furthermore, as shown in Figure 6 for Kuwait City climates, the yearly cooling load of the black roof $\left(1091 \mathrm{Wd} / \mathrm{m}^{2}\right)$ decreased to $730 \mathrm{Wd} / \mathrm{m}^{2}$ (i.e., a reduction in EC, Y by 49\%) and $592 \mathrm{Wd} / \mathrm{m}^{2}$ (i.e., a reduction in $\mathrm{EC}, \mathrm{Y}$ by $84 \%$ ) as a result of installing reflective cooling material at no cleaning condition and weekly cleaning condition, respectively.

For the Eastern Province of Saudi Arabia and Kuwait City's environmental conditions, respectively, the highest hourly black roofs' surface temperatures were $93.2{ }^{\circ} \mathrm{C}$ and $84.0^{\circ} \mathrm{C}$ compared to $65.4^{\circ} \mathrm{C}$ and $61.5^{\circ} \mathrm{C}$ for white roof at no cleaning condition, and $52.7^{\circ} \mathrm{C}$ and $52.6^{\circ} \mathrm{C}$ for white roofs at weekly cleaning conditions. The full results of the JUC-KISR project that include material characterizations, installing guidelines, cleaning procedures, test results, three-dimensional numerical results, etc., are available in [71,72].

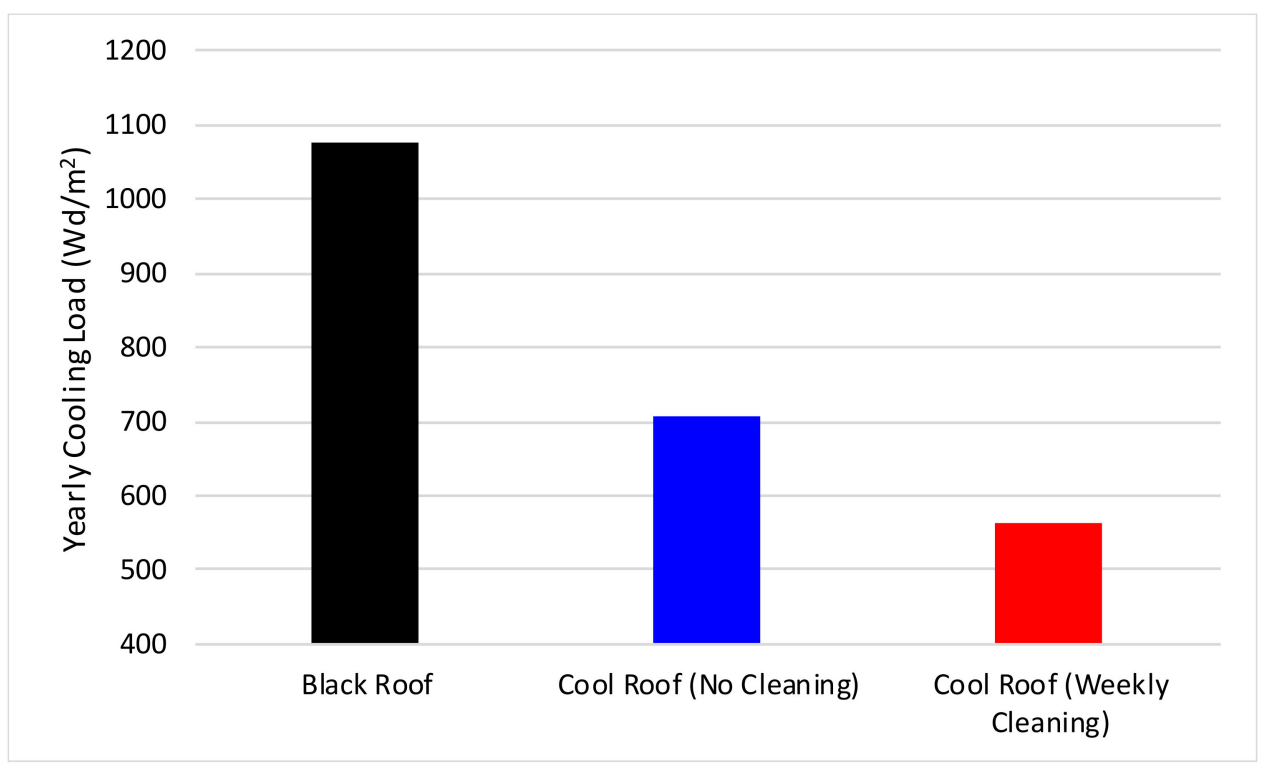

Figure 5. Comparison of the yearly cooling energy load of conventional/black roof and white roof based on no cleaning condition and weekly cleaning condition and subjected to Saudi Eastern Province climates [71,72]. 


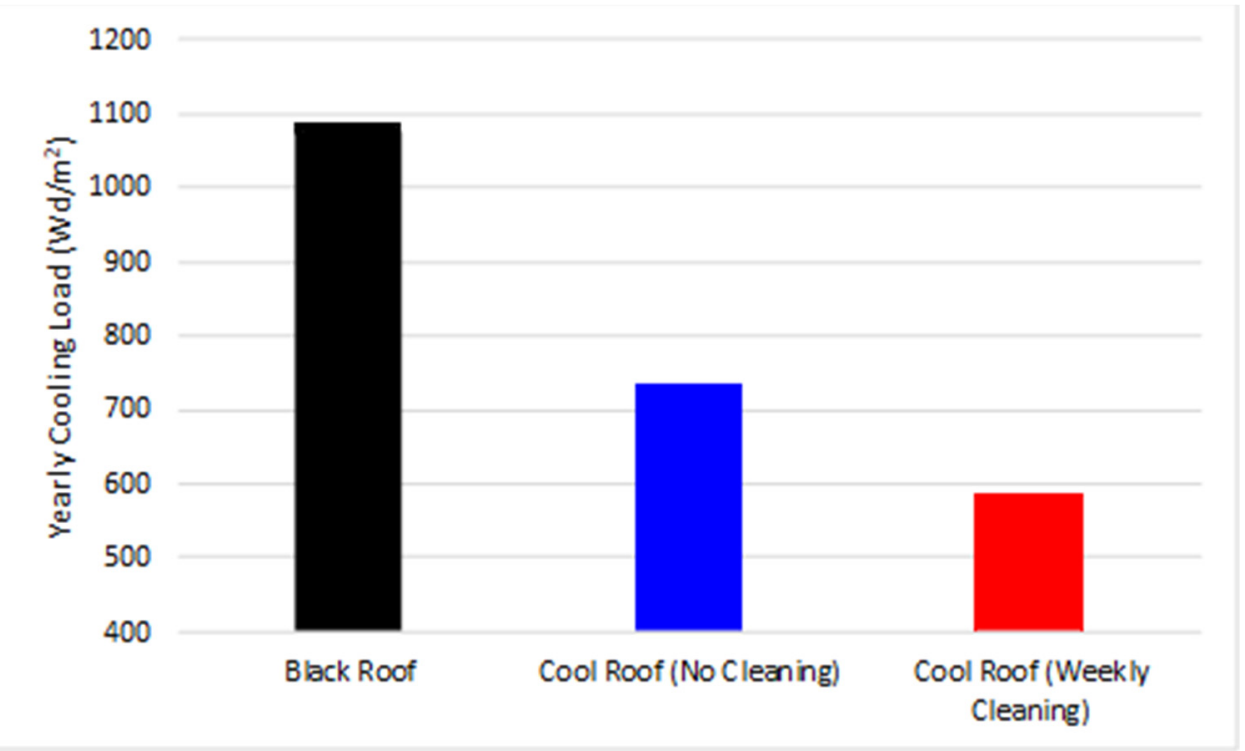

Figure 6. Comparison of the yearly cooling energy load of conventional/black roof and white roof based on no cleaning condition and weekly cleaning condition and subjected to Kuwait City climates [71,72].

In summary, a logical step towards achieving energy-efficient buildings in cities with extreme climatic conditions is to design roofing systems with simultaneous energy savings, no condensation and less risk of moisture problems. The main parameters affecting the energy and moisture performance of roofing systems are a type of roof, environmental conditions, amount of insulation and the solar reflectivity of the roofing surfaces. Several cleaning processes have been used to increase the solar reflectivity to reach approximately its initial value in case there is dust/dirt accumulation on the roofing surface.

\section{Conclusions}

This paper discussed in some depth the issue of white roofing materials and cool roofing technologies with a view to identifying how these technologies affect technology uptake and adoption. The technical aspects of what actually comprise white roofing solutions and cool roof technologies are explored in some depth. This paper reviewed most of the concepts of white roofing materials with the focus on their energy performance, costbenefit, maintenance process and their impact on the emergent countries. This paper gave a retrospective as well on the concept of different roofing systems that exist and identified differences among them such as Green/White/Reflective/Cool roofs. The emerging economies concept was explored and a tight relation that exists between the reflective roofing materials and these emerging economies were established. The link between energy demand, energy consumption, and climate change through the production of greenhouse gas emissions is irrefutable. While developed countries typically have the resources necessary to both develop new construction designs and technologies to reduce energy consumption and emissions, emergent economies lack such resources. On average, overall energy consumption globally among all countries is expected to increase by more than $100 \%$ by the year 2050 but in emerging economies, this figure is believed to be more than $300 \%$ on average. Hence, the emergent economy has to deploy energy-efficient building designs and integrate energy-efficient building envelope materials at the outset, thus, they can reduce this drastic gap in expected energy usage growth moving forward. Specifically, in the design phase of new construction, passive energy-efficient solutions greatly reduce forward energy demands per structure. The design-build phase of construction in emergent economies can address issues that have significant positive effects on energy consumption throughout the life of the structure. This paper discussed as well in some depth the issue 
of white roofing materials and cool roofing technologies with a view to identify how these technologies affect technology uptake and adoption. The technical aspects of what actually comprise white roofing solutions and cool roof technologies are explored in some depth. The study focused on cool roofing systems subjected to hot climates such as that in Gulf Cooperation Council (GCC) countries. Factors such as a cool roof's solar reflectance and its overall thermal emittance were reviewed. These two factors in particular are extremely critical from a technical perspective as well as a marketing-related perspective. This is because these two factors (solar reflectance and thermal emittance) generally determine the overall energy efficiency of the roofing technology selected.

Yet, these two factors also work to determine the character of a cool roof technology's marketing messaging, platform and purchase rationale because they directly relate to global issues such as climate change, energy savings and environmental responsibility, and so forth. In essence, while the technological characteristics of white roofing material and cool roof technologies are critical from performance-based perspectives, and a technology adoption perspective, these factors must be related to practical outcomes from a consumerrelated vantage point.

The adoption of white roof tiles or other non-white roof colours with high solar reflectance in countries subjected to tropical climates can be increased by spreading awareness among house owners, through various stakeholders, that emphasizes the cost savings that the house owners can enjoy, which can potentially, from the stance of the house owners, outweigh all of the other disadvantages. Thus, further research on the development of solar-reflective paint or coating products that can significantly increase the solar reflectance values of non-white roof tiles is essential to overcome issues related to maintenance difficulties and lack of preference among house buyers towards white roof tiles.

This review study has shown the importance in achieving energy-efficient building in cities with extreme climatic conditions by designing roofing systems that considered simultaneously the energy savings with less risk of moisture problems. The main parameters affecting the energy and moisture performance of roofing systems are types of roof, environmental conditions, amount of insulation and the solar reflectivity of the roofing surfaces. Several cleaning processes have been identified to increase the solar reflectivity to reach approximately its initial value in case there is dust/dirt accumulation on the roofing surface.

Author Contributions: Conceptualization, F.A.F. and W.M., Methodology, F.A.F. and W.M., Analysis, F.A.F., W.M. and M.M.A. investigation, F.A.F. and W.M., Resources, F.A.F., W.M. and M.M.A., Writing—original draft preparation, F.A.F. and W.M., Writing-Review and editing, F.A.F., W.M. and M.M.A. Project administration, F.A.F. and W.M. All authors have read and agreed to the published version of the manuscript.

Funding: This research received no external funding.

Institutional Review Board Statement: Not applicable.

Informed Consent Statement: Not applicable.

Data Availability Statement: Not applicable.

Conflicts of Interest: The authors declare no conflict of interest.

\section{References}

1. Peterson, T.C.; Gallo, K.P.; Lawrimore, J.; Owen, T.W.; Huang, A.; McKittrick, D.A. Global rural temperature trends. Geophys. Res. Lett. 1999, 26, 329-332. [CrossRef]

2. Huang, Q.; Lu, Y. The effect of urban heat island on climate warming in the Yangtze river delta urban agglomeration in China. Int. J. Environ. Res. Public Health 2015, 12, 8773-8789. [CrossRef]

3. Sachindra, D.A.; Ng, A.W.M.; Muthukumaran, S.; Perera, B.J.C. Impact of climate change on urban heat island effect and extreme temperatures: A case study. Q. J. R. Meteorol. Soc. 2016, 142, 172-186. [CrossRef]

4. Oleson, K.W.; Bonan, G.B.; Feddema, J. Effects of white roofs on urban temperature in a global climate model. Geophys. Res. Lett. 2010, 37, 3. [CrossRef] 
5. U.S. Environmental Protection Agency (EPA). Keeping Your Cool: How Communities Can Reduce the Heat Island Effect. Available online: https:/ / www.epa.gov/sites/production/files/2016-09/documents/heat_island_4-page_brochure_508_120413.pdf (accessed on 1 June 2019).

6. Saber, H.H.; Hajiah, A.E.; Alshehri, S.; Hussain, H.J. Investigating the Effect of Dust Accumulation on Solar Reflectivity of Coating Materials for Cool Roof Applications. Energies 2021, 14, 445. [CrossRef]

7. Aflaki, A.; Mirnezhad, M.; Ghaffarianhoseini, A.; Ghaffarianhoseini, A.; Omrany, H.; Wang, Z.-H.; Akbari, H. Urban Heat Island Mitigation Strategies: A State-of-the-Art Review on Kuala Lumpur, Singapore and Hong Kong. Cities 2017, $62,131-145$. [CrossRef]

8. Huang, M.; Cui, P.; He, X. Study of the cooling effects of urban green space in Harbin in terms of reducing the heat island effect. Sustainability 2018, 10, 1101. [CrossRef]

9. Nuruzzaman, M. Urban heat island: Causes, effects and mitigation measures-A review. Int. J. Environ. Monit. Anal. 2015, 3, 67-73. [CrossRef]

10. Sebastiani, A.; Marando, F.; Manes, F. Mismatch of regulating ecosystem services for sustainable urban planning: PM10 removal and urban heat island effect mitigation in the municipality of Rome (Italy). Urban For. Urban Green. 2021, 57, 126938. [CrossRef]

11. Mohajerani, A.; Bakaric, J.; Jeffrey-Bailey, T. The urban heat island effect, its causes, and mitigation, with reference to the thermal properties of asphalt concrete. J. Environ. Manag. 2017, 197, 522-538. [CrossRef]

12. Lee, J.S.; Kim, J.T.; Lee, M.G. Mitigation of urban heat island effect and greenroofs. Indoor Built Environ. 2014, 23, 62-69. [CrossRef]

13. U.S. Environmental Protection Agency. Cool Roofs. Reducing Urban Heat Islands: Compendium of Strategies. 2008. Available online: https: / / www.epa.gov/heat-islands/heat-island-compendium (accessed on 1 January 2019).

14. Saber, H.H.; Maref, W.; Hajiah, A.E. Hygrothermal Performance of Cool Roofs Subjected to Saudi Climates. J. Front. Energy Res. 2019, 7, 39. [CrossRef]

15. Saber, H.H.; Maref, W. Energy Performance of Cool Roofs Followed by Development of Practical Design Tool. J. Front. Energy Res. 2019, 7, 122. [CrossRef]

16. Saber, H.H. Hygrothermal Performance of Cool Roofs with Reflective Coating Material Subjected to Hot, Humid and Dusty Climate. J. Build. Phys. 2021. [CrossRef]

17. Saber, H.H. Experimental Characterization of Reflective Coating Material for Cool Roofs in Hot, Humid and Dusty Climate. Energy Build. 2021, 242, 110993. [CrossRef]

18. Al-Obaidi, K.M.; Ismail, M.; Abdul Rahman, A.M. Investigation of passive design techniques for pitched roof systems in the tropical region. Mod. Appl. Sci. 2014, 8, 182-191. [CrossRef]

19. Miranville, F.; Boyer, H.; Mara, T.; Garde, F. On the thermal behaviour of roof-mounted radiant barriers under tropical and humid climatic conditions: Modelling and empirical validation. Energy Build. 2003, 35, 997-1008. [CrossRef]

20. Lee, S.W.; Lim, C.H.; Chan, S.A.; Von, K.L. Techno-economic evaluation of roof thermal insulation for a hypermarket in equatorial climate: Malaysia. Sustain. Cities Soc. 2017, 35, 209-223. [CrossRef]

21. Vijaykumar, K.C.K.; Srinivasan, P.S.S.; Dhandapani, S. A performance of hollow tiles clay (HTC) laid reinforced cement concrete (RCC) roof for tropical summer climates. Energy Build. 2007, 39, 886-892. [CrossRef]

22. Ferrari, A.; Kubilay, A.; Derome, D.; Carmeliet, J. Design of smart wetting of building materials as evaporative cooling measure for improving the urban climate during heat Waves. E3S Web Conf. 2020, 03001. [CrossRef]

23. Berardi, U.; Ghaffarian Hoseini, A.H. State-of-the-art analysis of the environmental benefits of green roofs. Appl. Energy 2014, 115, 411-428. [CrossRef]

24. Berardi, U.; Gallardo, A.A. Properties of concretes enhanced with phase change materials for building applications. Energy Build. 2019, 199, 402-414. [CrossRef]

25. Hernández-Pérez, I.; Xam 'an, J.; Macías-Melo, E.V.; Aguilar-Castro, K.M.; Zavala- Guill'en, I.; Hernandez-L’opez, I.; Sim'a, E. Experimental thermal evaluation of building roofs with conventional and reflective coatings. Energy Build. 2018, 158, 569-579. [CrossRef]

26. Pisello, A.L. State of the art on the development of cool coatings for buildings and cities. Sol. Energy 2017, 144, 660-680. [CrossRef]

27. Hernández-Pérez, I. Influence of Traditional and Solar Reflective Coatings on the Heat Transfer of Building Roofs in Mexico. Appl. Sci. 2021, 11, 3263. [CrossRef]

28. Farhan, S.A.; Ismail, F.I.; Kiwan, O.; Shafiq, N.; Zain-Ahmed, A.; Husna, N.; Hamid, A.I.A. Effect of Roof Tile Colour on Heat Conduction Transfer, Roof-Top Surface Temperature and Cooling Load in Modern Residential Buildings under the Tropical Climate of Malaysia. Sustainability 2021, 13, 4665. [CrossRef]

29. Berdahl, P.; Akbari, H.; Levinson, R.; Miller, W.A. Weathering of roofing materials-An overview. Constr. Build. Mater. 2008, 22, 423-433. [CrossRef]

30. Suehrcke, H.; Peterson, E.L.; Selby, N. Effect of roof solar reflectance on the building heat gain in a hot climate. Energy Build. 2008, 40, 2224-2235. [CrossRef]

31. Mani, M.; Pillai, R. Impact of dust on solar photovoltaic (PV) performance: Research status, challenges and recommendations. Renew. Sustain. Energy Rev. 2010, 14, 3124-3131. [CrossRef]

32. Sulaimana, S.A.; Singhb, A.K.; Mokhtara, M.M.M.; Bou-Rabeec, M.A. Influence of dirt accumulation on performance of pv panels. Energy Procedia 2014, 50, 50-56. [CrossRef] 
33. Algarni, S.; Nutter, D. Influence of dust accumulation on building roof thermal performance and radiant heat gain in hot-dry climates. Energy Build. 2015, 104, 181-190. [CrossRef]

34. Levinson, R.; Berdahl, P.; Asefawberhe, A.; Akbari, H. Effects of soiling and cleaning on the reflectance and solar heat gain of a light-colored roofing membrane. Atmos. Environ. 2005, 39, 7807-7824. [CrossRef]

35. Akbari, H.; Berhe, A.; Levinson, R.; Graveline, S.; Foley, K.; Delgado, A.H.; Paroli, R.M. Aging and Weathering of Cool Roofing Membranes. In Proceedings of the First International Conference on Passive and Low Energy Cooling for the Built Environment, Athens, Greece, 17 May 2005.

36. Saber, H.H.; Swinton, M.C.; Kalinger, P.; Paroli, R.M. Long-term hygrothermal performance of white and black roofs in North American climates. Build. Environ. 2012, 50, 141-154. [CrossRef]

37. Alkhalifa, A.H.; Al-Homaidan, A.A.; Shehata, A.I.; Al-Khamis, H.H.; Al-Ghanayem, A.A.; Ibrahim, A.S.S. Brown macroalgae as bio-indicators for heavy metals pollution of Al-Jubail coastal area of Saudi Arabia. Afr. J. Biotechnol. 2012, 11, 15888-15895.

38. Al-A'ama, M.S.; Nakhla, G.F. Wastewater reuse in Jubail, Saudi Arabia. Water Res. 1995, 29, 1579-1584. [CrossRef]

39. Saber, H.H.; Swinton, M.C.; Kalinger, P.; Paroli, R.M. Hygrothermal simulations of cool reflective and conventional roofs. In Proceedings of the 2011 NRCA International Roofing Symposium, Emerging Technologies and Roof System Performance, Washington, DC, USA, 7-9 September 2011.

40. Alchapar, N.L.; Correa, E.N. Aging of roof coatings. Solar reflectance stability according to their morphological characteristics. Constr. Build. Mater. 2016, 102, 297-305. [CrossRef]

41. Muscio, A. The Solar Reflectance Index as a Tool to Forecast the Heat Released to the Urban Environment: Potentiality and Assessment Issues. Climate 2018, 6, 12. [CrossRef]

42. Ziolo, M.; Jednak, S.; Savic, G.; Kragulj, D. Link between energy efficiency and sustainable economic and financial development in OECD countries. Energies 2020, 13, 5898. [CrossRef]

43. Technology Roadmap: Energy Efficient Building Envelopes; International Energy Agency: Paris, France, 2013; Volume 7, pp. 1-68.

44. Ochedi, E.T.; Taki, A.; Painter, B. Low cost approach to energy efficient buildings in Nigeria: A review of passive Design Options. In Proceedings of the 21st Century Human Habitat: Issues, Sustainability and Development, Akure, Nigeria, 21-24 March 2016; Available online: https:/ / dora.dmu.ac.uk/handle/2086/11876 (accessed on 1 June 2021).

45. Tsafos, N. Energy Transitions in Emerging Economies: What Success Looks like and How to Replicate It; CSIS: Jakarta, Indonesia, 2020; Volume 12, pp. 1-9.

46. Santamouris, M. Minimizing Energy Consumption, Energy Poverty and Global and Local Climate Change in the Built Environment: Innovating to Zero: Causalities and Impacts in a Zero Concept World; Elsevier: Amsterdam, The Netherlands, 2018.

47. Feng, W.; Zhang, Q.; Ji, H.; Wang, R.; Zhou, N.; Ye, Q.; Lau, S.S.Y. A review of net zero energy buildings in hot and humid climates: Experience learned from 34 case study buildings. Renew. Sustain. Energy Rev. 2019, 114, 109303. [CrossRef]

48. Al-Homoud, D.M.S. Performance characteristics and practical applications of common building thermal insulation materials. Build. Environ. 2005, 40, 353-366. [CrossRef]

49. Solecki, W.D.; Rosenzweig, C.; Parshall, L.; Pope, G.; Clark, M.; Cox, J.; Wiencke, M. Mitigation of the heat island effect in urban New Jersey. Glob. Environ. Chang. Part B Environ. Hazards 2005, 6, 39-49. [CrossRef]

50. Green Public Procurement Thermal Insulation Technical Background Report. 2010. Available online: https://ec.europa.eu/ environment/gpp/pdf/thermal_insulation_GPP_\%20background_report.pdf (accessed on 1 June 2021).

51. Krarti, M.; Hajiah, A. Analysis of impact of daylight time savings on energy use of buildings in Kuwait. Energy Policy 2011, 39, 2319-2329. [CrossRef]

52. Zirkelbach, D.; Schafaczek, B.; Künzel, H. Long-term hygrothermal performance of green roofs. In Proceedings of the Eleventh International Conference on Thermal Performance of the Exterior Envelopes of Whole Buildings XI, Clearwater, FL, USA, 4-8 December 2016.

53. Ismail, A.; Samad, M.H.A.; Rahman, A.M.A. The investigation of green roof and white roof cooling potential on single storey residential building in the Malaysian climate. Proc. World Acad. Sci. Eng. Technol. 2011, 76, 129-137.

54. Jo, J.H.; Carlson, J.; Golden, J.S.; Bryan, H. Sustainable urban energy: Development of a mesoscale assessment model for solar reflective roof technologies. Energy Policy 2010, 38, 7951-7959. [CrossRef]

55. Levinson, R.; Akbari, H.; Berdahl, P.; Wood, K.; Skilton, W.; Petersheim, J. A novel technique for the production of cool colored concrete tile and asphalt shingle roofing products. Sol. Energy Mater. Sol. Cells 2010, 94, 946-954. [CrossRef]

56. Xu, T.; Sathaye, J.; Akbari, H.; Garg, V.; Tetali, S. Quantifying the direct benefits of cool roofs in an urban setting: Reduced cooling energy use and lowered greenhouse gas emissions. Build. Environ. 2012, 48, 1-6. [CrossRef]

57. Vrachopoulos, M.; Koukou, M.; Stavlas, D.; Stamatopoulos, V.; Gonidis, A.; Kravvaritis, E. Testing reflective insulation for improvement of buildings energy efficiency. Open Eng. 2012, 2, 83-90. [CrossRef]

58. Akbari, H.; Konopacki, S.; Pomerantz, M. Cooling energy savings potential of reflective roofs for residential and commercial buildings in the United States. Energy 1999, 24, 391-407. [CrossRef]

59. Akbari, H.; Konopacki, S.; Parker, D. Updates on revision to ASHRAE standard 90.2: Including roof reflectivity for residential buildings. Proc. ACEEE Summer Study Energy Effic. Build. 2000, 1, 11-111.

60. Levinson, R.; Akbari, H. Potential benefits of cool roofs on commercial buildings: Conserving energy, saving money, and reducing emission of greenhouse gases and air pollutants. Energy Effic. 2010, 3, 53-109. [CrossRef] 
61. Ray, S.; Glicksman, L. Potential energy savings of various roof technologies. In Proceedings of the Eleventh International Conference on Thermal Performance of the Exterior Envelopes of Whole Buildings XI, Clearwater, FL, USA, 4-8 December 2016.

62. Maref, W. For Better Performance of the Building Envelope: Improvement and Complexity, ASHRAE Virtual Conference, Seminar 67-Back to the Future on High Efficiency Design and Operation. In Proceedings of the ASHRAE Annual Meeting, Austin, TX, USA, 30 June 2020.

63. Natural Resources Canada (NRCan). Energy Efficiency Trend in Canada de 1990 à 2013; Cat. No. M141-1E-PDF; Natural Resources Canada: Ottawa, ON, Canada, 2016. Available online: https://www.nrcan.gc.ca/energy/publications/19030 (accessed on 1 June 2019).

64. International Energy Agency (IEA). World Energy Outlook Special Report: Energy and Climate Change; International Energy Agency: Paris, France, 2015.

65. Mchugh, B.; Petrick, R. Chicago's green and garden roofing codes and technology. In Proceedings of the 2011 international Roofing Symposium, Washington, DC, USA, 7-9 September 2011.

66. Durhman, A.; Collins, M.; Mcgillis, W.R. Utilizing green technology and research to assess green roofing benefits. In Proceedings of the 2011 International Roofing Symposium, Washington, DC, USA, 7-9 September 2011.

67. Bentz, S.P. Decision-making process for green options in reroofing. In Proceedings of the 2011 International Roofing Symposium, Washington, DC, USA, 7-9 September 2011.

68. Peltier, R.; Lee, S.; Hennigan, C.; Arhami, E. Urban Meteorology. 2018. Available online: https://slideplayer.com/slide/7880769/ (accessed on 1 June 2021).

69. Li, H. Evaluation of Cool Pavement Strategies for Heat Island Mitigation [Improving Outdoor Thermal Environment in Hot Climates through Cool Pavement Design Strategies]; Final Research Report [D05-4]; Institute of transportation studies, Department of Civil Environmental Engineeing, Unversity of California: Davis, CA, USA, 2012; Available online: https:/ / escholarship.org/content/ qt6mr4k9t1/qt6mr4k9t1_noSplash_9ab61b14762e84b7d61994b7aa5e0d1b.pdf?t=pyhuvm (accessed on 1 June 2021).

70. Green Roofs. Reducing Urban Heat Islands: Compendium of Strategies: Heat IslandReduction Activities. 2018. Available online: https:/ / healthyplacesindex.org/wp-content/uploads/2018/01/epa_heat_island_reduction_activities.pdf. (accessed on 1 June 2021).

71. Saber, H.H.; Alshehri, S.A.; Alnofaie, M.; Alghamdi, A.; Alraghi, S.; Hajiah, A.E. Energy Savings Due to Using Reflective Roofing Materials in Buildings of Kuwait and Saudi Arabia. Client Report-Part II. Unpublished work. 2020.

72. Saber, H.H.; Hajiah, A.E. 3D Numerical Modeling for Assessing the Energy Performance of Single- and Two-Zone Buildings with and without Phase Change Materials. In Proceedings of the Gulf Conference on Sustainable Built Environment, Kuwait City, Kuwait, 10-13 March 2019; pp. 10-13.

73. Hajiah, A.E.; Saber, H.H. Long-Term Energy and Moisture Performance of Reflective and Non-Reflective Roofing Systems with and without Phase Change Materials under Kuwaiti Climates. In Proceedings of the Gulf Conference on Sustainable Built Environment, Kuwait City, Kuwait, 10-13 March 2019; pp. 10-13.

74. Green Technologies and Energy Efficiency (GTEE 2017) workshop at the King Faisal University in Saudi Arabia, 26 April 2017. Available online: https://img0cf.b8cdn.com/images/course/35/68573835_1594764313.pdf (accessed on 1 June 2021).

75. Pisello, A.L.; Castaldo, V.L.; Pignatta, G.; Cotana, F.; Santamouris, M. Experimental in-lab and in-field analysis of waterproof membranes for cool roof application and urban heat island mitigation. Energy Build. 2016, 114, 180-190. [CrossRef]

76. Miller, W.; Crompton, G.; Bell, J. Analysis of Cool Roof Coatings for Residential Demand Side Management in Tropical Australia. Energies 2015, 8, 5303-5318. [CrossRef]

77. William, R.; Goodwell, A.; Richardson, M.; Le, P.V.; Kumar, P.; Stillwell, A.S. An environmental cost-benefit analysis of alternative green roofing strategies. Ecol. Eng. 2016, 95, 1-9. [CrossRef]

78. Saber, H.H.; Maref, W.; Abdulghani, K. Properties and Position of Materials in the Building Envelope for Housing and Small Buildings; National Research Council of Canada: Ottawa, ON, Canada, 2014.

79. Saber, H.H.; Maref, W. Risk of condensation and mould growth in wood-frame wall systems with different exterior insulations. In Proceedings of the Building Enclosure Science \& Technology Conference (BEST4 Conference), Kansas City, MO, USA, 16 April 2015.

80. Lacasse, M.A.; Saber, H.H.; Maref, W.; Ganapathy, G.; Plescia, S.; Parekh, A. Field Evaluation of Thermal and Moisture Response of Highly Insulated Wood-Frame Walls. In Proceedings of the 13th International Conference on Thermal Performance of the Exterior Envelopes of Whole, Buildings XIII, Clearwater, FL, USA, 4-8 December 2016.

81. Saber, H.H.; Lacasse, M.A.; Ganapathy, G.; Plescia, S.; Parekh, A. Risk of condensation and mould growth in highly insulated wood-frame walls. In Proceedings of the 13th International Conference on Thermal Performance of the Exterior Envelopes of Whole, Buildings XIII, Clearwater, FL, USA, 4-8 December 2016.

82. Saber, H.H.; Lacasse, M.A.; Moore, T.V. Hygrothermal performance assessment of stucco-clad wood frame walls having vented and ventilated drainage cavities. In Advances in Hygrothermal Performance of Building Envelopes: Materials, Systems and Simulations, ASTM STP1599; ASTM International: West Conshohocken, PA, USA, 2017; pp. 198-231.

83. Brehob, E.; Desjarlais, A.; Atchley, J. Effectiveness of cool roof coatings with ceramic particles. In Proceedings of the 2011 International Roofing Symposium, Washington, DC, USA, 7-9 September 2011.

84. Urban, B.; Roth., K. Guidelines for Selecting Cool Roofs. Building Technologies Program; 2010. Available online: https: //www.energy.gov / sites / prod / files /2013/10/f3 / coolroofguide.pdf (accessed on 1 June 2021). 
85. Ennis, M.; Kehrer, M. The effects of roof membrane color on moisture accumulation in low-slope commercial roof systems. In Proceedings of the 2011 international roofing symposium, Oak Ridge, TN, USA, 1 January 2011.

86. Bludau, C.; Zirkelbach, D.; Kuenzel, H.M. Condensation problems in cool roofs. Interface J. RCI 2009, XXVII, 11-16.

87. Bludau, C.; Künzel, H.M.; Zirkelbach, D. Hygrothermal performance of flat roofs with construction moisture. In Proceedings of the Eleventh International Conference on Thermal Performance of the Exterior Envelopes of Whole Buildings, Clearwater, FL, USA, 4-8 December 2016.

88. Saber, H.H.; Alshehri, S.A.; Alnofaie, M.; Alghamdi, A.; Alraghi, S.; Hajiah, A.E. Energy Savings Due to Using Reflective Roofing Materials in Buildings of Kuwait and Saudi Arabia; Internal and Client Report (Confidenti-Part I); Kuwait Institute for Scientific Research (KISR): Kuwait City, Kuwait, 2019; Volume 67. 